\title{
Potential Effects of Host Height and Phenology on Adult Susceptibility to Foliar Attack in Tropical Dry Forest Grass
}

\author{
Bráulio A. Santos, Mauricio Quesada, Fernando Rosas, and Julieta Benítez-Malvido \\ Centro de Investigaciones en Ecosistemas, Universidad Nacional Autónoma de México (UNAM), \\ Antigua Carretera a Pátzcuaro No. 8701, Ex Hacienda de San José de la Huerta, 58190 Morelia, MICH, Mexico \\ Correspondence should be addressed to Bráulio A. Santos, bsantos@oikos.unam.mx
}

Received 31 January 2011; Accepted 29 March 2011

Academic Editors: P. Coley and D. Sánchez-Fernández

Copyright ( $\odot 2011$ Bráulio A. Santos et al. This is an open access article distributed under the Creative Commons Attribution License, which permits unrestricted use, distribution, and reproduction in any medium, provided the original work is properly cited.

Identifying the sources of variation in plant susceptibility to herbivore and pathogen attack is critical to understand ecological processes determining species abundance and diversity in tropical forests. We assessed the potential effect of tiller height and phenology on standing levels of herbivore and pathogen damage on adults of the woody perennial grass Lasiacis ruscifolia in the tropical dry forest of Chamela, Mexico. Analyses revealed that adult susceptibility to pathogens was greater in small and fruiting tillers than in taller and leaf flushing tillers. Adult susceptibility to herbivores, on the other hand, varied greatly among plants and had no relationship with tiller height and phenology. Our findings suggest that adults highly susceptible to pathogen attack could augment the negative density and distance dependence effects predicted by the Janzen-Connell hypothesis, with potential consequences for the local distribution of the studied species in the forest.

\section{Introduction}

Spatial variation in plant susceptibility to herbivore and pathogen attack is the basis for one of the most accepted mechanisms determining plant species coexistence in tropical forests [1-3]. This mechanism, widely known as JanzenConnell hypothesis $[4,5]$, postulates that host-specific herbivores and pathogens reduce recruitment near conspecific adults or where conspecific seed density is high, leaving space free for the establishment of other plant species. Biotic damage occurs more often during early ontogenetic stages (e.g., seed and seedling stages), commonly resulting in host debilitation and/or death. Resistance usually increases with ontogeny $[6,7]$, but adults keep being attacked by a similar pool of specialized enemies. In this sense, highly susceptible adults may represent unsuitable ("unsafe") sites for nearby seed germination and seedling recruitment and thereby augment the distance and density effects predicted by the Janzen-Connell hypothesis. Alternatively, adults with low susceptibility may function as "safe" sites for earlier ontogenetic stages recruiting nearby, reducing the negative effects of density and distance dependence.

Despite the importance of adults as potential reservoirs of host-specific pests and diseases, there is still little information about their susceptibility to herbivore and pathogen attack in tropical forests. In the presence of these natural enemies, variation in adult susceptibility may arise from phenotypic differences among individuals caused by genetic or environmental factors. Differences in plant size and phenology, for instance, are expected to generate variation in the nutritive value of plant tissues as well as in plant ability to resist or tolerate the damage after herbivore/pathogen recognition [813]. The main reason for this variation in host quality and defensive levels is the physiological tradeoff between growth and reproduction [14], which may constrain resources for defense and result in a mosaic of host susceptibility [15] according to their phenotypic characteristics. Given the high environmental heterogeneity of tropical dry forests [16], a high spatial variation in plant size and phenology (a complex mosaic) is expected for a given species occupying different microhabitats of the forest. This variation, in turn, 


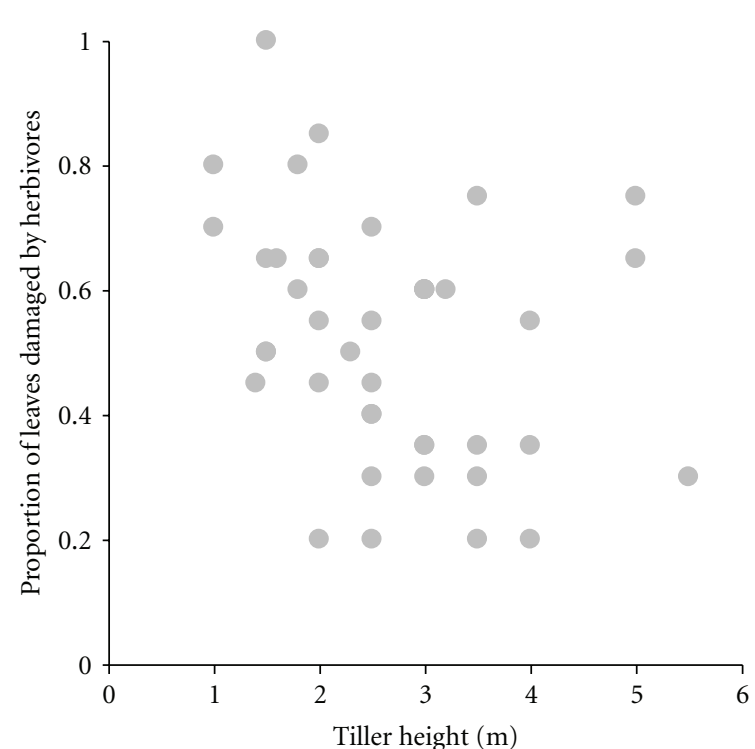

(a)

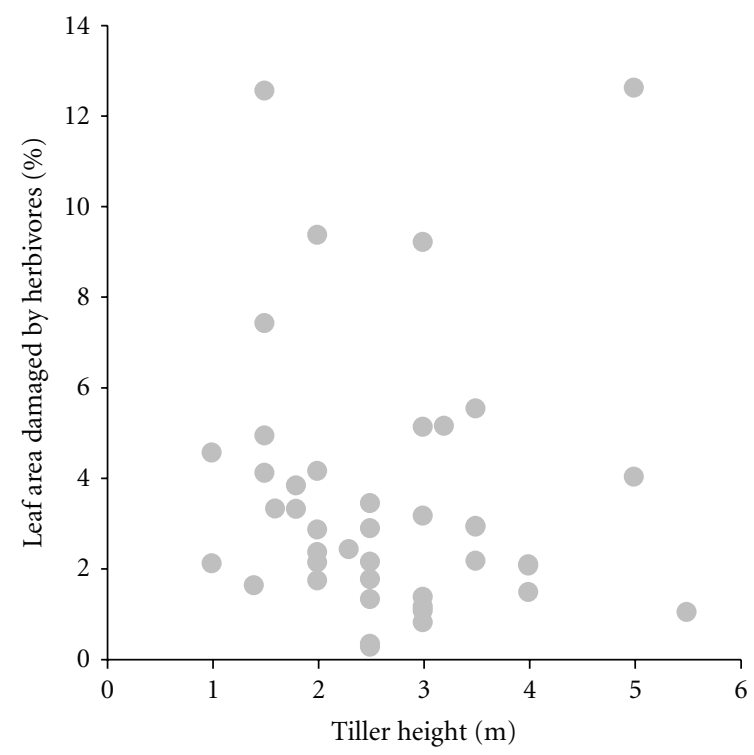

(c)

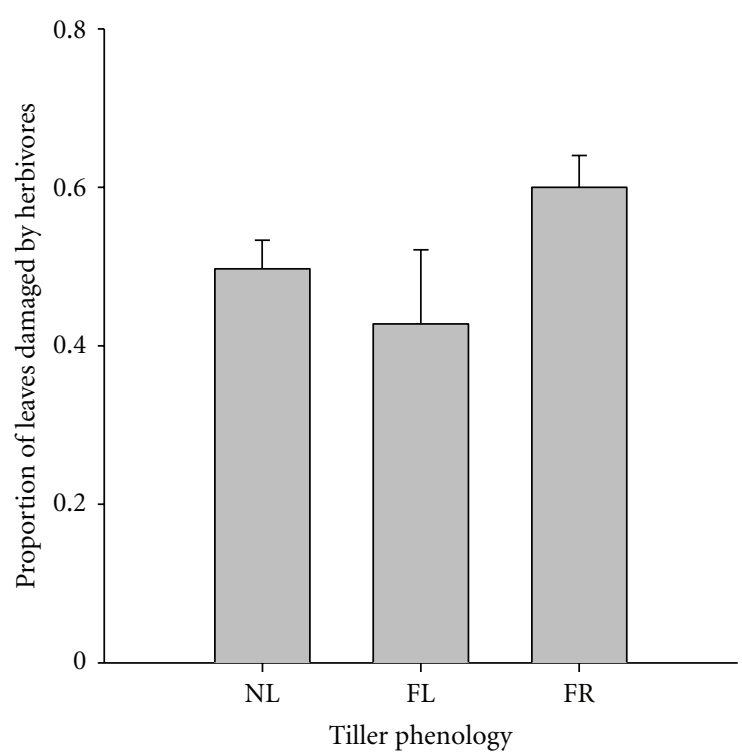

(b)

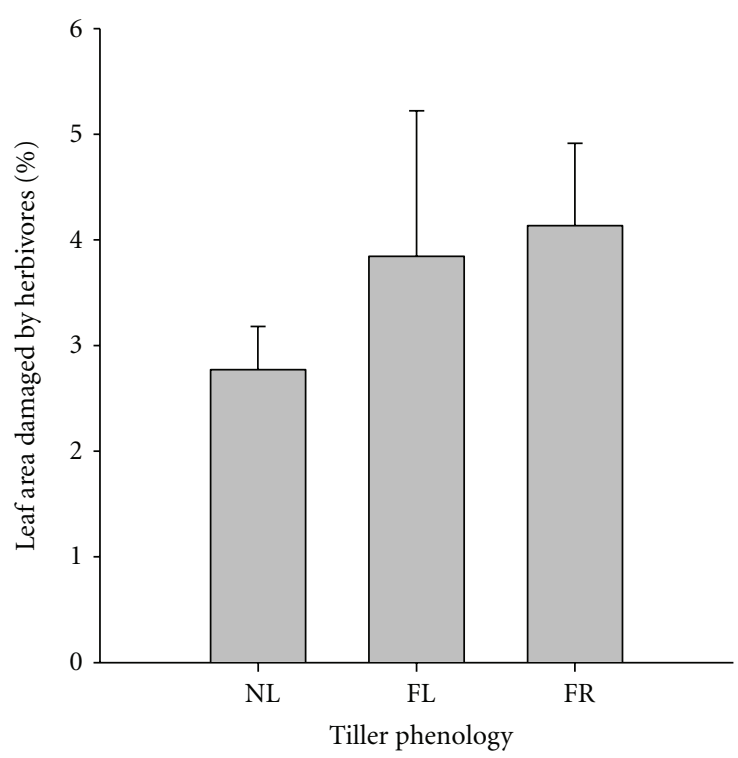

(d)

Figure 1: Effect of tiller height (a-b) and phenology (c-d) on the incidence and severity of herbivore damage in Lasiacis ruscifolia at the Chamela-Cuixmala Biosphere Reserve, Mexico. NL: tiller flushing new leaves; FL: flowering tiller; FR: fruiting tiller.

is expected to be translated into a gradient of adult susceptibility to herbivore and pathogen attack, with potential consequences for pest and disease incidence on surrounding conspecifics.

In this study we sampled adult individuals of the Neotropical perennial woody grass Lasiacis ruscifolia (Poaceae) in a Mexican tropical dry forest to assess two major questions. How large is the local spatial variation in tiller height and phenological stage in this species? Does a correlation exist between these life-history traits and the standing levels of foliar damage caused by herbivores and pathogens? We selected Lasiacis ruscifolia as study system because (1) it occupies a variety of microhabitats in the study area (e.g., forest understory, canopy gaps, different soils); (2) it is easily identifiable at any phenological stage; (3) there is published information on the herbivores and pathogens attacking its leaves; finally (4) it occurs in many ecosystems throughout the Neotropics, so it could be useful in future comparative studies.

\section{Methods}

2.1. Study Site. We conducted this study in the ChamelaCuixmala Biosphere Reserve, Pacific coast of Jalisco, Mexico. The reserve covers an area of about 13,000 ha distributed between $0-500 \mathrm{~m}$ asl. Average annual precipitation is 


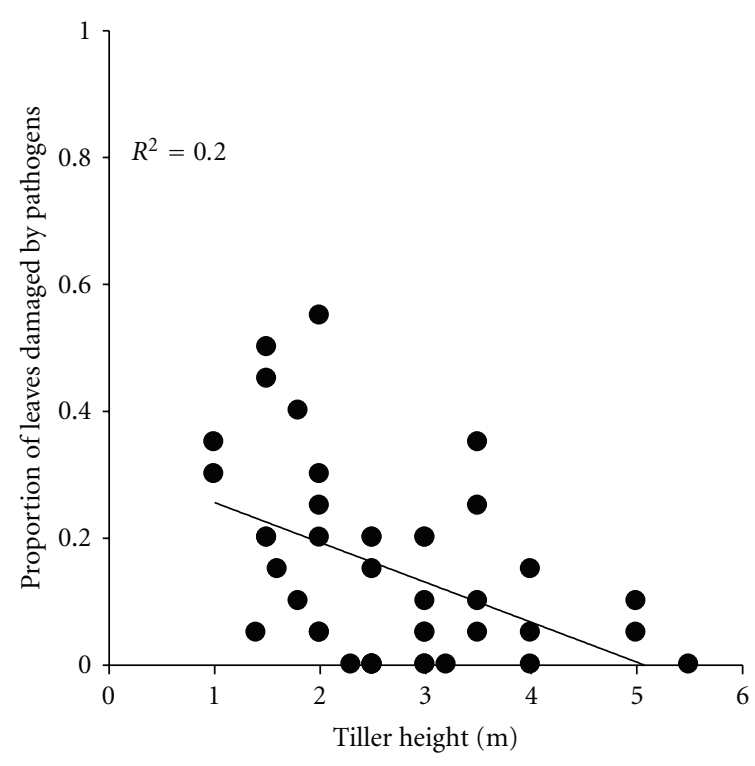

(a)

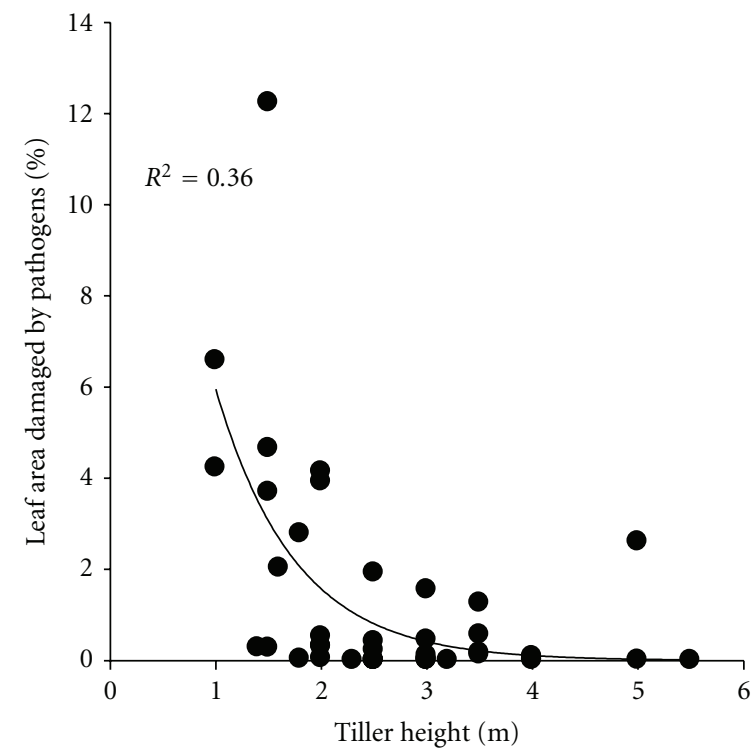

(c)

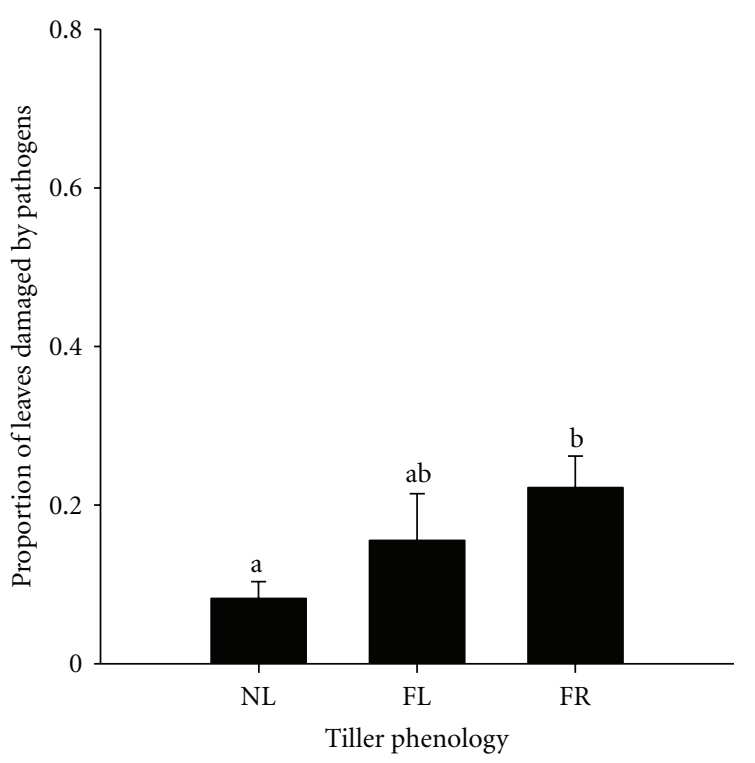

(b)

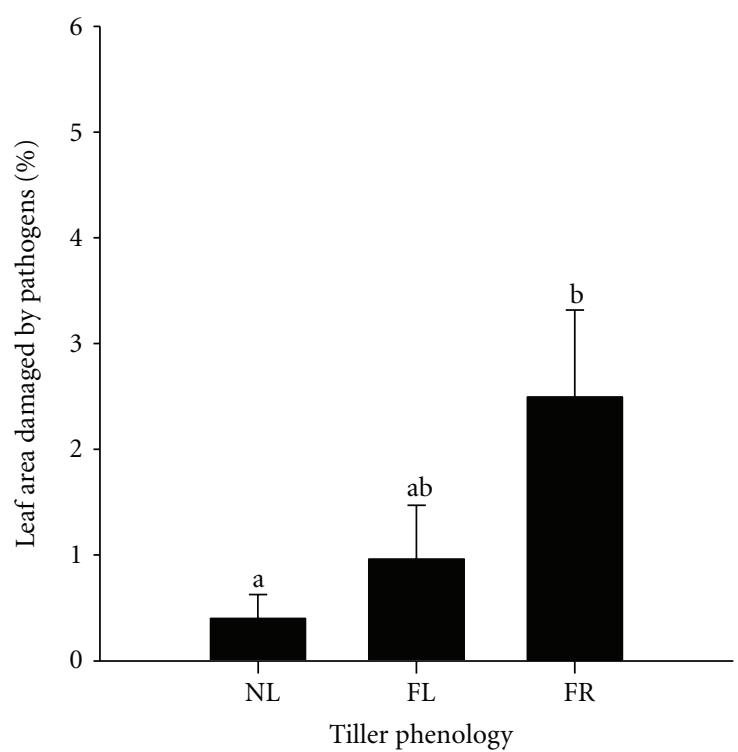

(d)

FIGURE 2: Effect of tiller height (a-b) and phenology (c-d) on the incidence and severity of pathogen damage in Lasiacis ruscifolia at the Chamela-Cuixmala Biosphere Reserve, Mexico. NL: tiller flushing new leaves; FL: flowering tiller; FR: fruiting tiller. Different letters indicate significant difference among means by Tukey-Kramer HSD method $(\alpha=0.05)$.

$748 \mathrm{~mm}$, with a rainy season from June to October. The reserve is dominated by tropical deciduous forest, with patches of tropical riparian forest along the streams [17]. A detailed description of the flora, fauna, soil, and climate can be found in Noguera et al. [18], including information on insect herbivore diversity and seasonality. There is very scarce information on plant pathogens of Chamela. The available information indicates that around 35\% of 294 plant species surveyed in the region are attacked by leaf fungal pathogens and that the huge majority of the attacked species (92\%) present leaf spots, whereas only $8 \%$ are infected by rusts [19]. There is no information on temporal variation of pathogen attack.
2.2. Studied Species. The grass Lasiacis ruscifolia (H.B.K.) Hitchc. var ruscifolia (Poaceae) occurs throughout the Neotropics in elevations lesser than $1000 \mathrm{~m}[20,21]$. It is common in dry deciduous forests, coastal thickets, and gallery forests, but it also occurs along wet forest margins and shrub communities [20]. In Chamela it is very common and easily distinguished from the other 56 native species of Poaceae [22]. Its woody culms are scandent, $1-8 \mathrm{~m}$ long and $5-12 \mathrm{~mm}$ in diameter [21]. The woodiness is not due to secondary growth, but to a large amount of lignified primary tissue [20]. The tiller, which includes the culm and its associated leaves, is perennial and can take two years to reach maturity [20]. Leaf blades are $4-16 \mathrm{~cm}$ long and $1-5 \mathrm{~cm}$ wide, 
TABLE 1: Results of generalized linear mixed models applied to test for the effect of tiller height and phenology on the incidence and severity of herbivore and pathogen damage in Lasiacis ruscifolia. Restricted maximum likelihood method was used to separate the variance of fixed effects from that of the random effect, thus no $F$ value and its associated $P$ value and degrees of freedom are calculated for the random effect (see Section 2).

\begin{tabular}{|c|c|c|c|c|c|c|}
\hline Model term & $\mathrm{df}$ & df den & $F$-ratio & $P$ value & $\%$ Error variance & Model $R^{2}(\%)$ \\
\hline Herbivory incidence & & & & & & 72.2 \\
\hline Height & 1 & 28.74 & 2.182 & .151 & - & \\
\hline Phenology & 2 & 32.34 & 1.647 & .208 & - & \\
\hline Height $\times$ phenology & 2 & 26.89 & 2.661 & .088 & - & \\
\hline Plant (random) & - & & - & - & 51.5 & \\
\hline Residual & - & & - & - & 48.5 & \\
\hline Herbivory severity & & & & & & 36.0 \\
\hline Height & 1 & 35.09 & 1.922 & .177 & - & \\
\hline Phenology & 2 & 32.41 & 2.152 & .133 & - & \\
\hline Height $\times$ phenology & 2 & 32.32 & 2.136 & .138 & - & \\
\hline Plant (random) & - & & - & - & 16.1 & \\
\hline Residual & - & & - & - & 83.9 & \\
\hline Disease incidence & & & & & & 33.9 \\
\hline Height & 1 & 35.67 & 3.106 & .087 & - & \\
\hline Phenology & 2 & 28.07 & 3.737 & .036 & - & \\
\hline Height $\times$ phenology & 2 & 34.50 & 0.977 & .386 & - & \\
\hline Plant (random) & - & & - & - & -1.0 & \\
\hline Residual & - & & - & - & 101.0 & \\
\hline Disease severity & & & & & & 40.9 \\
\hline Height & 1 & 35.96 & 4.524 & .040 & - & \\
\hline Phenology & 2 & 28.40 & 3.903 & .032 & - & \\
\hline Height $\times$ phenology & 2 & 33.81 & 0.170 & .844 & - & \\
\hline Plant (random) & - & & - & - & 2.5 & \\
\hline Residual & - & & - & - & 97.5 & \\
\hline
\end{tabular}

with surface glabrous to hispid and margin scabrous [21]. New leaves unfurl in few days and leaf lifespan is expected to be greater than a year. Leaf epidermis contains several structures that can act as defense against natural enemies, such as silica cells, microhairs, prickle hair, and macrohairs [20]. The species is anemophilous, self-compatible, and its major mode of pollination under natural conditions is selfpollination [20]. Larvae of Vettius fantasos, $V$. diversa maeon, $V$. coryna conka, and V. aurelius (Lepidoptera: Hesperiinae) are known to feed on their leaves ([23] and references therein), but they are also attacked by larvae of Manataria maculata (Lepidoptera: Satyrinae), which feeds on other species of the genus Lasiacis as well [24]. The rust fungi Uromyces leptodermus and Phakopsora lenticularis infect their leaves $[25,26]$, but they are also prone to be infected by other rusts (Uromyces costaricensis and Puccinia lasiacidis) [26].

2.3. Data Collection. To assess the relationship between adult phenotype and susceptibility to foliar attack we arbitrarily selected 15 small clumps of the species at the beginning of the dry season (November 2008). At this moment, most of the herbivore populations decline and conditions for fungal infection may be not the best (see [18, 27]), but the damage they caused during the previous seasons (rainy and dry) is accumulated in the foliage. Clumps were at least $50 \mathrm{~m}$ apart from each other and presented between 4 and 11 tillers (mean $=7$ ). We randomly chose three tillers per clump, measured them in height, and took note on their phenological stage (i.e., flushing new leaves, flowering, or fruiting). Then we collected 20 mature leaves (10 at the base and 10 at the apex of the tiller) to estimate the levels of biotic damage. We used a 7-megapixel digital camera and a blue background panel to photograph all collected leaves $(N=900)$. Photographs were processed in the image analysis software ASSESS [28] to quantify the incidence (i.e., presence/absence of leaf damage) and severity (i.e., percentage of leaf area removed/infected) of biotic damage. These two measures were used to evaluate the levels of susceptibility.

2.4. Statistical Analyses. To test for the effect of tiller height and phenology on the incidence and severity of foliar damage we used generalized linear mixed models (GLMMs). Host height, phenology, and their interaction were set as fixed effects, and the individual plant (plant 1 to 15) was set as random effect to account for tiller dependence in the same 
clump. Dependent variables, that is, proportion of leaves attacked and mean percentage of leaf area damaged, were arcsine-square-root transformed prior to analyses. We ran GLMMs in JMP 7 (SAS Institute Inc.) using the restricted maximum likelihood method to separate the variance of fixed effects from that of random effects. No $F$ value and its associated $P$ value and degrees of freedom are calculated for the random effect; the percentage of the error variance attributed to it is calculated instead. All-pairs Tukey-Kramer HSD method was used a posteriori to compare means among the levels of the host phenology effect. We present untransformed data in figures to facilitate comprehension.

\section{Results}

Tillers varied from 1.0 to $5.5 \mathrm{~m}$ in height and showed reproductive structures (flowers or fruits) over all this range, confirming that the tillers we sampled were adults. Tillers greatly varied in their phenological stage, including those within the same individual, indicating high asynchrony in phenological events. Precisely, seventeen of the 45 tillers were flushing new leaves, 9 were in flower, 16 were in fruit, 1 presented flowers and fruits, and 2 had no flowers or fruits. The two latter phenological stages were excluded from the GLMMs due to lack of replicates, totaling 42 tillers analyzed. All the 45 tillers sampled presented herbivore damage, but $10(22 \%)$ escaped from fungal attack. In general, tillers had about half of their leaves attacked by herbivores (frequency of $0.52 \pm 0.03$; mean \pm SE) and a sixth of their leaves attacked by leaf pathogens $(0.15 \pm 0.02)$. Severity of biotic damage was low (on average $<5 \%$ of leaf area), but the percentage of leaf area damaged by herbivores was three times higher than that damaged by pathogens $(3.4 \pm 0.4 \%$ versus $1.4 \pm 0.3 \%)$.

Herbivore attack did not vary significantly with tiller height, phenology, and their interaction (Table 1; Figure 1). Instead, it greatly varied from plant to plant as indicated by the high percentage of error variance attributed to the random factor "plant" (16-51\%, Table 1). Pathogen attack, on the other hand, varied significantly with tiller height and phenology, except for the effect of height on disease incidence $(P=.087$, Table 1$)$. In general, smaller and fruiting tillers presented greater levels of pathogen attack than taller and leaf flushing tillers (Figure 2). The random effect "plant" had a negligible effect on pathogen attack, explaining lesser than $2.5 \%$ of the error variance (Table 1 ).

\section{Discussion}

The study of plant susceptibility to biotic damage has long been an exciting topic in tropical biology (e.g., $[4,5,29-$ 34]). After the formal presentation of the Janzen-Connell hypothesis in the earlier 70s, an extensive number of studies have examined their assumptions and predictions in a variety of species and tropical ecosystems (reviewed by Wright [3]). Most of the empirical evidence accumulated so far does indicate that host-specific herbivores and pathogens help to maintain the high local diversity of plant species in hyperdiverse biological communities (e.g., $[1,35])$. Nevertheless, some important questions remain unanswered, and one of them refers to the role of adult susceptibility to pests and diseases in augmenting or reducing the negative effects of distance and density dependence on new conspecific recruits.

Our analyses revealed a great spatial variation among Lasiacis ruscifolia adults in terms of plant size and phenology. This variation in phenotype had a weak effect on susceptibility to herbivores, but a clear effect on susceptibility to pathogens. Although the relationships between phenotype and level of susceptibility we found are not proof of causality, our findings suggest that smaller and fruiting tillers may represent "unsafe" sites for the recruitment of conspecifics in terms of pathogen attack, as pathogen susceptibility correlated negatively with tiller height and was greater at the end of the reproductive cycle [36-39]. These relationships were consistent among plants, which increases predictability of pathogen attack if plants with similar phenotype are spatially clustered. Further evidence of reduced recruitment near clumps of smaller and fruiting tillers is needed to validate the additive effect of susceptible adults to the negative consequences of density and distance dependence postulated by the Janzen-Connell hypothesis.

The weak effect of host height and phenology on susceptibility to herbivore can be explained by the high variation in herbivore attack observed across plants with similar phenotypic characteristics. This high variation may be caused by numerous biological and physical processes that operate at the scale of the host plant or the entire community. For instance, at the plant scale, it is likely that the physiological tradeoff between host growth and reproduction does not compromise the levels of antiherbivore defenses. This possibility is supported by the fact that silica, the main substance involved in grass defense against herbivores [40-42], can be passively deposited in plant tissues without reducing photosynthetic activity ([43] and references therein, [44]); reductions occur only when silica concentration is exceptionally high (e.g., $>25 \%$ of leaf dry mass, [43]). At the community level, the high variation in herbivore attack among plants may be associated with differences in the availability of alternative host plants to Lasiacis herbivores, presence of predators and parasitoids, and suitable microclimatic conditions for herbivore growth and reproduction. Nevertheless, whatever the source of the variation among plants, our results suggest that "safe" or "unsafe" sites for herbivores cannot be predicted by tiller height and phenology.

To summarize, our results suggest that adult susceptibility to pathogens on Lasiacis ruscifolia can be predicted by host height and phenology, with potential effects for the recruitment of conspecifics. Namely, small and fruiting tillers could maximize the negative effects of density and distance dependence in terms of pathogen attack. Adult susceptibility to herbivore damage, on the other hand, cannot be predicted by host height and phenology. Further studies manipulating seed/seedling density near clumps of tillers differing in height and phenology would be useful to produce a more comprehensive picture on how adult susceptibility to biotic damage influences the establishment of new individuals in natural conditions. 


\section{Acknowledgments}

The authors thank Ek del Val and Octavio Sánchez for valuable comments made on previous drafts of this paper. The Estación de Biología Chamela (Instituto de Biología UNAM) and the Posgrado en Ciencias Biológicas (UNAM) provided infrastructure and logistic support during the field work. They are also grateful to CONACyT-Mexico for graduate scholarship to B. A. Santos, postdoctoral fellowship to F. Rosas, and research grants to J. Benítez-Malvido and M. Quesada.

\section{References}

[1] K. E. Harms, S. J. Wright, O. Calderón, A. Hernández, and E. A. Herre, "Pervasive density-dependent recruitment enhances seedling diversity in a tropical forest," Nature, vol. 404, no. 6777, pp. 493-495, 2000.

[2] G. S. Gilbert, "Evolutionary ecology of plant diseases in natural ecosystems," Annual Review of Phytopathology, vol. 40, pp. 13-43, 2002.

[3] S. J. Wright, "Plant diversity in tropical forests: a review of mechanisms of species coexistence," Oecologia, vol. 130, no. 1, pp. 1-14, 2002.

[4] D. H. Janzen, "Herbivores and the number of tree species in tropical forests," American Society of Naturalists, vol. 104, pp. 501-527, 1970.

[5] J. H. Connell, "On the role of natural enemies in preventing competitive exclusion in some marine animals and in the rain forest trees," in Dynamics of Populations, P. J. den Boer and G. R. Gradwell, Eds., pp. 298-310, Centre for Agriculture Publications and Documentation, Wageningen, The Netherlands, 1971.

[6] K. Boege, "Herbivore attack in Casearia nitida influenced by plant ontogenetic variation in foliage quality and plant architecture," Oecologia, vol. 143, no. 1, pp. 117-125, 2005.

[7] M. P. Develey-Rivière and E. Galiana, "Resistance to pathogens and host developmental stage: a multifaceted relationship within the plant kingdom," New Phytologist, vol. 175, no. 3, pp. 405-416, 2007.

[8] T. C. R. White, "An index to measure weather-induced stress of trees associated with outbreaks of psyllids in Australia," Ecology, vol. 50, pp. 905-909, 1969.

[9] D. F. Rhoades, "Evolution of plant chemical defenses against herbivory," in Herbivores: Their Interaction with Secondary Plant Metabolites, G. A. Rosenthal and D. H. Janzen, Eds., pp. 3-54, Academic Press, New York, NY, USA, 1979.

[10] P. W. Price, "The plant vigor hypothesis and herbivore attack," Oikos, vol. 62, no. 2, pp. 244-251, 1991.

[11] C. S. Awmack and S. R. Leather, "Host plant quality and fecundity in herbivorous insects," Annual Review of Entomology, vol. 47, pp. 817-844, 2002.

[12] A. Kessler and I. T. Baldwin, "Plant responses to insect herbivory: the emerging molecular analysis," Annual Review of Plant Biology, vol. 53, pp. 299-328, 2002.

[13] B. Pariaud, V. Ravigné, F. Halkett, H. Goyeau, J. Carlier, and C. Lannou, "Aggressiveness and its role in the adaptation of plant pathogens," Plant Pathology, vol. 58, no. 3, pp. 409-424, 2009.

[14] S. C. Stearns, "Trade-offs in life-history evolution," Functional Ecology, vol. 3, pp. 259-268, 1989.

[15] J. N. Thompson, The Geographic Mosaic of Coevolution, University of Chicago Press, Chicago, Ill, USA, 2005.
[16] S. H. Bullock, H. A. Mooney, and E. Medina, Seasonally Dry Tropical Forests, Cambridge University Press, Cambridge, UK, 1995.

[17] J. Rzedowski, Vegetación de México, Editorial Limusa, México, Mexico, 1978.

[18] F. A. Noguera, J. H. Vega Rivera, A. N. García Aldrete, and M. A. Quesada, Historia Natural de Chamela, Instituto de Biologia-UNAM, México, Mexico, 2002.

[19] G. García-Guzmán and E. Morales, "Life-history strategies of plant pathogens: distribution patterns and phylogenetic analysis," Ecology, vol. 88, no. 3, pp. 589-596, 2007.

[20] G. Davidse, "A systematic study of the genus Lasiacis (Gramineae: Paniceae)," Annals of the Missouri Botanical Garden, vol. 65, pp. 1133-1254, 1978.

[21] W. D. Clayton, K. T. Harman, and H. Williamson, "GrassBaseThe Online World Grass Flora," 2006, http://www.kew.org/ data/grasses-db.html.

[22] E. J. Lott, "Lista anotada de plantas vasculares de ChamelaCuixmala," in Historia Natural de Chamela, F. A. Noguera, J. H. Vega Rivera, A. N. García Aldrete, and M. A. Quesada, Eds., pp. 99-136, Instituto de Biologia-UNAM, México, Mexico, 2002.

[23] H. F. Greeney and A. D. Warren, "The life history and shelter building behavior of vettius coryna coryna hewitson, 1866 in eastern ecuador (Lepidoptera: Hesperiidae: Hesperiinae)," Journal of Insect Science, vol. 9, Article ID 32, 2009.

[24] L. Murillo and K. R. Nishida, "Life history of Manataria maculata (Lepidoptera: Satyrinae) from Costa Rica," Revista de Biologia Tropical, vol. 51, no. 2, pp. 463-469, 2003.

[25] E. B. Mains, "Angiopsora, a new genus of rusts on grasses," Mycologia, vol. 26, pp. 122-132, 1934.

[26] J. F. Hennen, M. B. Figueiredo, A. A. Carvalho, and F. G. Hennen, Catalogue of the Species of Plant Rust Fungi (Uredinales) of Brazil, FAPESP, CNPq, FAPERJ, NSF, and USDA, Sao Paulo, Brazil, 2005.

[27] G. N. Agrios, Plant Pathology, Elsevier Academic Press, London, UK, 5th edition, 2005.

[28] L. Lamari, Assess: Image Analysis Software for Plant Disease Quantification, The American Phytopathological Society, Winnipeg, Canada, 2002.

[29] C. K. Augspurger, "Seed dispersal of the tropical tree, Platypodium elegans, and the escape of its seedlings from fungal pathogens," Journal of Ecology, vol. 71, no. 3, pp. 759-771, 1983.

[30] C. K. Augspurger, "Seedling survival of tropical tree species: interactions of dispersal distance, light-gaps, and pathogens," Ecology, vol. 65, no. 6, pp. 1705-1712, 1984.

[31] J. Benitez-Malvido, G. García-Guzmán, and I. D. KossmannFerraz, "Leaf-fungal incidence and herbivory on tree seedlings in tropical rainforest fragments: an experimental study," Biological Conservation, vol. 91, no. 2-3, pp. 143-150, 1999.

[32] J. Benítez-Malvido and A. Lemus-Albor, "The seedling community of tropical rain forest edges and its interaction with herbivores and pathogens," Biotropica, vol. 37, no. 2, pp. 301313, 2005.

[33] G. García-Guzmán and R. Dirzo, "Patterns of leaf-pathogen infection in the understory of a Mexican rain forest: incidence, spatiotemporal variation, and mechanisms of infection," American Journal of Botany, vol. 88, no. 4, pp. 634-645, 2001.

[34] G. García-Guzmán and R. Dirzo, "Incidence of leaf pathogens in the canopy of a Mexican tropical wet forest," Plant Ecology, vol. 172, no. 1, pp. 41-50, 2004. 
[35] D. J. Bradley, G. S. Gilbert, and J. B. H. Martiny, "Pathogens promote plant diversity through a compensatory response," Ecology Letters, vol. 11, no. 5, pp. 461-469, 2008.

[36] P. R. Scott, P. W. Benedikz, and C. J. Cox, "A genetic study of the relationship between height, time of ear emergence and resistance to Septoria nodomm in wheat," Plant Pathology, vol. 31, pp. 45-60, 1982.

[37] G. S. Gilbert, "Rain forest plant diseases: the canopyunderstory connection," Selbyana, vol. 15, pp. 75-77, 1995.

[38] A. Mesterházy, "Types and components of resistance to Fusarium head blight of wheat," Plant Breed, vol. 114, pp. 377386, 1995.

[39] A. J. Hilton, P. Jenkinson, T. W. Hollins, and D. W. Parry, "Relationship between cultivar height and severity of Fusarium ear blight in wheat," Plant Pathology, vol. 48, no. 2, pp. 202-208, 1999.

[40] S. J. McNaughton, J. L. Tarrants, M. M. McNaughton, and R. D. Davis, "Silica as a defense against herbivory and a growth promotor in African grasses," Ecology, vol. 66, pp. 528-535, 1985.

[41] M. Vicari and D. R. Bazely, "Do grasses fight back? The case for antiherbivore defences," Trends in Ecology and Evolution, vol. 8, no. 4, pp. 137-141, 1993.

[42] F. P. Massey, A. Roland Ennos, and S. E. Hartley, "Herbivore specific induction of silica-based plant defences," Oecologia, vol. 152, no. 4, pp. 677-683, 2007.

[43] H. Motomura, K. Hikosaka, and M. Suzuki, "Relationships between photosynthetic activity and silica accumulation with ages of leaf in Sasa veitchii (Poaceae, Bambusoideae)," Annals of Botany, vol. 101, no. 3, pp. 463-468, 2008.

[44] D. J. Gibson, Grasses and Grassland Ecology, Oxford University Press, New York, NY, USA, 2009. 

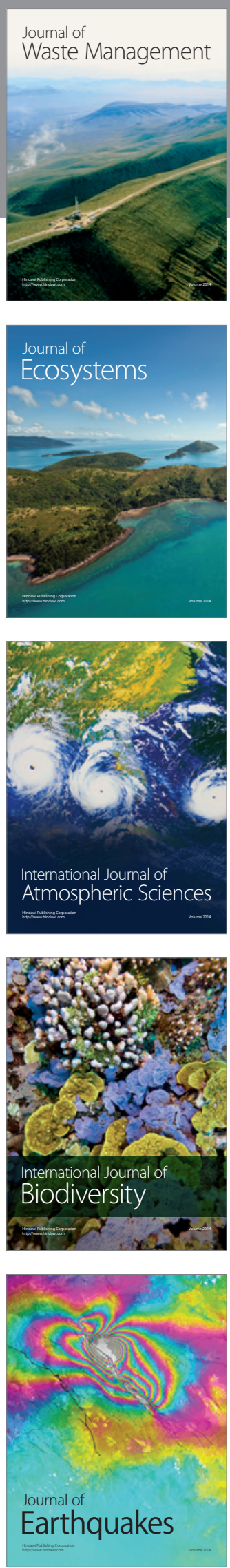
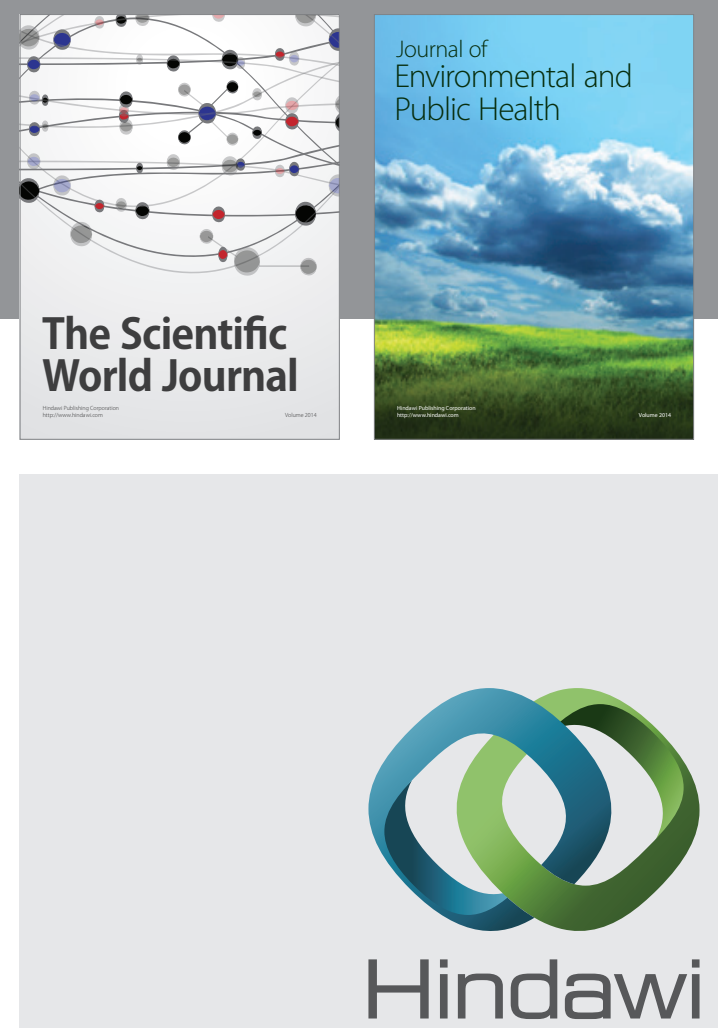

Submit your manuscripts at

http://www.hindawi.com
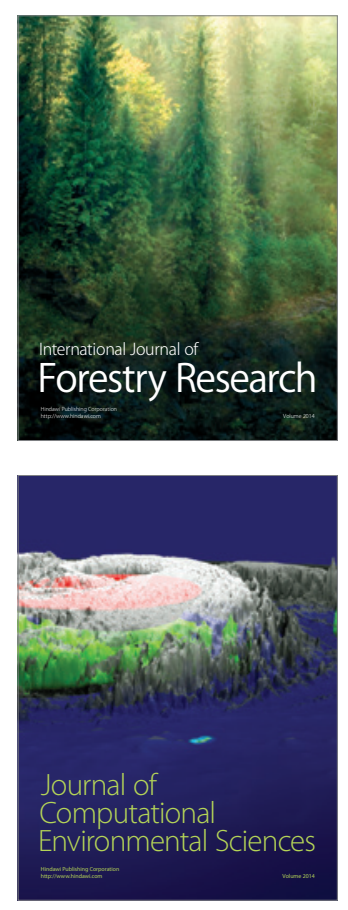
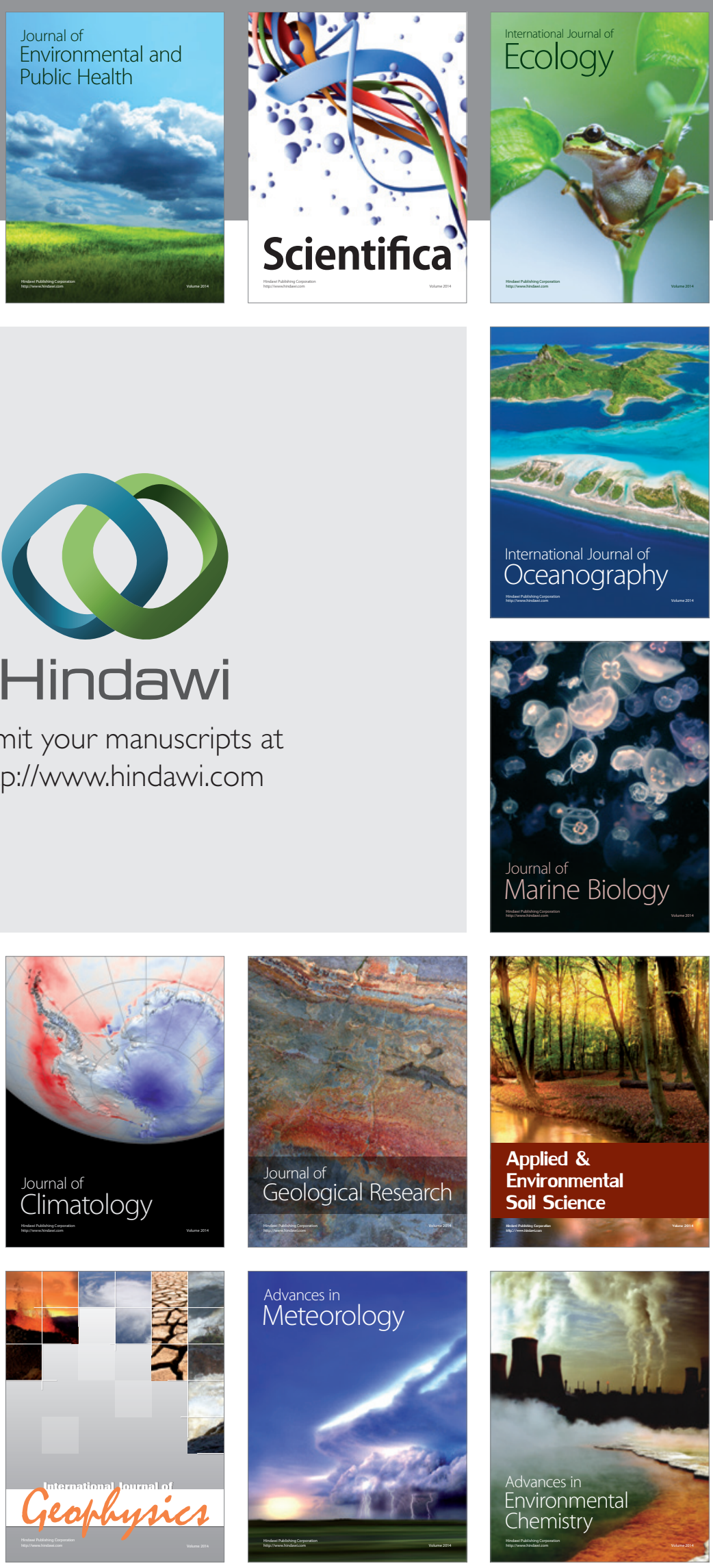